\title{
Feliz dia do trabalho
}

Bruna da Penha de Mendonça Coelho ${ }^{1}$

Feliz dia do trabalho, disse um vampiro

Não do trabalhador

Aquele que tenta sobreviver

Que tudo faz, tudo produz

Cuja cruz pesa, como a de um certo Jesus

Que eles fingem conhecer

Feliz dia do trabalho, disse um vampiro

Não do trabalhador

Aquele que no suor da lida

Dribla a ferida em carne rubra

Da sua própria existência moída

Na máquina de moer vida

Feliz dia do trabalho, eles desejaram

1 Mestra em Teoria e Filosofia do Direito pelo Programa de Pós-Graduação em Direito da Universidade do Estado do Rio de Janeiro (fevereiro de 2019). Graduada em direito pela UERJ (dezembro de 2016). Professora substituta de Prática Trabalhista da Faculdade Nacional de Direito (UFRJ). Intercâmbio acadêmico na Universitat Jaume I (UJI - Castellón de la Plana, Espanha) em 2013.2. Possui textos acadêmicos e literários publicados, dentre os quais os livros Do outro lado da Alcântara: Devaneios quase póstumos (Juruá editora, 2016), O samba carioca e a centralidade do trabalho vivo: Poetas operários (Juruá editora, 2019) e Seres humanos em terceiro plano: Uma análise da terceirização no Brasil (NEAOmniScriptum, 2019). Principais áreas de interesse de pesquisa: sociologia do trabalho; sociologia e filosofia do direito; literatura; direito material e processual do trabalho. 
Não do trabalhador

Que escárnio, que baixeza

Dessas bocas que bradam torpezas

Que só desejam a um operário

Um soco diário e um calvário 